\title{
On the Popularization of Digital Network Language Laboratory
}

\author{
Ying Luo ${ }^{1, \text { a }}$, Miaomiao $\mathrm{Li}^{2, \mathrm{~b}}$ \\ ${ }^{1}$ TVET Research Institute; Jiangxi Science \& Technology Normal University; Nanchang, China \\ ${ }^{2}$ Education School; Jiangxi Science \& Technology Normal University, Nanchang, China \\ amooonly@126.com; ${ }^{\mathrm{b}}$ LiMiaomiao0710@163.com
}

Keywords: digital network; language lab; network; popularization

\begin{abstract}
Digital network language lab has a powerful function and advantage in teaching, and has begun to gradually replace the traditional language lab. This paper introduces the characteristics and advantages of the digital network language lab, also analyzes the possible problems in the process of using, and puts forward the corresponding countermeasures: to set up a team of laboratory management with high quality; to strengthen the professional quality of teachers and improve the utilization of language lab; to increase the security investment; etc.
\end{abstract}

\section{Introduction}

In recent years, with the development of multimedia and network teaching technology, many colleges and universities have realized the digitization and networking, combined the traditional language teaching technology with the networking teaching technology, and set up digital network language lab. Digital network language lab realizes the new automatic, interactive and network language classroom teaching that the traditional language lab can not achieve. It can not only provide a series of digital teaching means, rich material database, and network communication means, but also can provide multimedia and network learning environment for students, which can make the language teaching become lively and vivid.

With the development of language education and teaching reform, the language lab responds more and more teaching task. For example, the experimental teaching for English major and public English listening course, entrance English examination, autonomous English learning in spare time, etc. The hierarchy, specification and range of the object serving by the language lab management is improving, teachers and students have higher requirements on the quality and level of service, so the management is facing severe challenges. It is particularly important to strengthen the management of digital network language lab and give full play to the function of language room.

\section{The advantages and characteristics of digital network language lab}

More powerful functions. The core technology of digital network lab is the computer technology and network technology. From the view of the accuracy of information transmission, digital audio and video transmission has the characteristic of high fidelity; the system eliminates the noise and the sound quality is more clear and accurate. At the same time, the expand of the system function is very strong. It not only contains all the functions of the traditional system, but also increases video on demand, electronic reading, conversation practice, tests and other dozens of application function, even can develop new features according to the demand. In addition, the stability and usability is incomparable by the traditional.

More abundant resources. The biggest characteristic of network technology is sharing mass information and resource. When teachers are choosing teaching materials, the resources are equal to the sum of all the information of the school. In the process of preparing lessons, teaching materials just need to click the mouse and are very convenient. Similarly, learning range is not only limited to the tape, and each student can use mass data provided by the campus network.

Higher utilization rate. From the view of utilization efficiency, although the initial investment of digital network lab is more than traditional lab, the period rate is very high. Because of abundant 
function, digital language lab is equivalent to the organic integration of speech classroom, simulation examination room, electronic reading room and so on. What's more, it can be used in class and after class. Therefore, the digital network language lab makes phonetic experiment teaching become a set of teaching system including listening, teaching, examination, analysis and statistics, which can not only provide more rich teaching methods for teachers, but also provide lively, vivid and relaxed learning environment for students.

\section{Problems exist in the application and management of digital network language lab}

Back education ideas make the basic function of digital network language lab not fully exploited and low utilization in implicit function. The control platform of digital network language lab is mainly operated by the press. After simple training, it is simple for foreign language teachers to master the use skill. However, many teachers' modern education concept is backward at present and are only satisfied with playing courseware and listening materials through digital network language lab. Most of teachers not only have not formed a kind of "big education" concept, but also have not formed "open education”, "interactive teaching” and "individual teaching” consciousness.

Lacking the support of a large number of teacher courseware system hinders the advantage of digital network language lab. Courseware is an important pillar of modern digital network language lab. Without enough teaching courseware, it is difficult to use the teaching system to increase the amount of teaching information and enrich the content of classroom teaching.

Limit device access. The main control machine in language lab should set up a username and password for each teacher, and preserve properly to avoid students to operate the main control machine unauthorized. For the student terminal, it should limit their access to the network to avoid them to do things having no relation with learning.

The students' autonomous learning lacks monitoring, and the advantage of digital network language lab can not be given full play. The function of self learning is an important characteristic of digital network language lab which is different from analog voice room. Through independent learning, students can request program autonomously, file read, listen circularly and record; after class, they can inquiry independently, request any material in database, carry out self learning according to their demand assisted by read, fast forward, fast rewind and other operations. But teachers always lack control and can not deal with the problems encountered in learning.

The problem of network security is a major problem bothering managers all the time. The cost of equipment in digital network language lab is high, the universality of device is also high, and the majority of components is compatible with computer; at the same time, university teaching building is always in the open state, personnel fluidity is great, and the identity is not easy to identify, therefore, the risk of equipment loss is relatively large.

\section{Measures improving the management of digital network language lab}

Set up a team of laboratory management with high quality. First of all, fully understand the role of lab team. Their task is to cultivate compound and innovative talents. So, it is necessary to establish a lab team with strong quality to make the device's benefit into full play, so as to improve the quality of personnel training. Secondly, strengthen the occupation morality of management personnel. Some better measures, such as, political and ideological education, to cultivate their sense of responsibility and recognize the importance of their work. In addition, the business ability of the language lab management staff should also be improved. Some training plans can be made periodically for managers, or organize them to participate in different forms of training, so as to broaden their horizon, improve their thinking ability, and promote their development. The last is to fully implement the incentive mechanism to motivate their mobilization.

Strengthen the professional quality of teachers and improve the utilization of language lab. Whether the teacher grasp the function of multimedia language room will directly affect the utilization. Strengthening teachers' pre job training mainly includes teaching advanced teaching ideas and methods, and operation procedure of multimedia language room, which can make them 
fully understand and grasp the function and usage of voice equipment, constantly enhance the information literacy, strengthen the information consciousness, improve the ability of information obtaining, processing, and transmission, and set up the consciousness of "open education", "interactive teaching" and "individual teaching". At the same time, when making courseware, teachers should strive to be concise, scientific and practical, and be consistent with the new teaching models and methods to improve teaching efficiency.

Expand the network storage capacity of campus network. In order to minimize the use of mobile storage equipment, we can establish vertical storage server in the campus network and set the storage space for the users. In this way, teachers and students can login in their space through a user name and password, edit and download the courseware and data. At the same time, the school can arrange a number of basic data to be stored in public space and let campus users download conveniently, which not only reduces the search time, but also reduces the possibility of network virus infection.

Perfecting language lab management system and strengthening the implementation of the management process is the behavior norm of the whole management process. Making scientific management system is the important guarantee to the standardization, scientification of language lab management. Formulating the language lab management system should be convenient for teachers and students to use and manage. Only in this way, the system can become the code of conduct of all teachers and students in the whole management process, be implemented effectively, and received the due effects. The rules and regulations established should include service regulations of digital network language lab, job responsibilities of language lab, lab safety regulations, equipment damage compensation methods, etc.

Increase the security investment. In addition to installing traditional anti-theft doors and windows, modernized means should be used to strengthen the security work. The first is to install infrared alarm system. When the language lab is closed, once the interior has abnormal situation, the system can find quickly and alarm. The second is to install video surveillance system. It can not only guard against theft, but also can supervise the classroom teaching situation. In addition, according to the actual situation of the school, entrance guard system can also be installed in centralized floor or the whole teaching building to identify the personnel through the entry card and avoid the external personnel to enter the teaching area unauthorized.

\section{Conclusion}

As a platform of university foreign language teaching, digital network language lab not only enrich the traditional classroom teaching mode, but also increase the vitality of classroom. Therefore, we must take feasible measures according to the problems of language lab, solve the problems timely, so as to better exert the advantages of digital network language lab in university foreign language teaching and improve the teaching effect. At the same time, study further to make the function and management level of digital network language lab improve continuously, so as to enhance the teaching quality of digital network language lab.

\section{Reference}

[1]Guiying Ren, Mingzi Cui. On the application and management of digital network language lab[J]. Chinese light education, 2008,29(2).

[2]Guanping Xie. Application and management of digital network language lab[J].Chinese light education, 2008.

[3]Can Yan. The effective use and management of foreign language lab in colleges[J]. Journal of Hunan Tax College, 2009,22(2).

[4]Haibo Wang. foreign language teaching and the construction of digital language lab[J]. Chinese modern education equipment, 2006(6):85. 
[5]Xiaojun Yang. Scientific management of digital network language lab[J]. Chinese business (the first half), 2010(07):358.

[6]Haihua Zhang. On the existing problems and countermeasures of language lab management in colleges[J]. Jiangsu science and technology information, 2011(3):116-117.

[7]Baiju Liang. Management and maintenance countermeasure of college language lab[J]. Chines technology and information, 2006(1):127-128.

[8]Guilin Zhao. The status and countermeasures of university autonomous listening speech room[J]. Journal of Shanxi Normal university: natural science edition, 2008(S1):135-136. 